\title{
PENINGKATAN MOTIVASI BELAJAR MATEMATIKA MELALUI MODEL PEMBELAJARAN THINK PAIR SHARE SISWA KELAS 4 SDN SIDOREJO LOR 01 KOTA SALATIGA
}

\author{
Gemi Sumarliningsih', Wasitohadi2, Theresia Sri Rahayu ${ }^{3}$ \\ ${ }^{1}$ Pendidikan Guru Sekolah Dasar, Universitas Kristen Satya Wacana Salatiga, 292014074@student.uksw.edu \\ ${ }^{2}$ Pendidikan Guru Sekolah Dasar, Universitas Kristen Satya Wacana, wasitohadi@staff.uksw.edu \\ ${ }^{3}$ Pendidikan Guru Sekolah Dasar, Universitas Kristen Satya Wacana, th.rahayu@gmail.com
}

\section{INFO ARTIKEL}

Riwayat Artikel:

Diterima: $23-03-2018$

Disetujui: $04-04-2018$

\section{Kata Kunci:}

Model Think Pair Share Motivasi Belajar

Matematika

\begin{abstract}
ABSTRAK
Abstrak: Jenis penelitian ini adalah penelitian tindakan kelas yang bertujuan untuk meningkatkan motivasi belajar matematika siswa kelas 4 SDN Sidorejo Lor 01 melalui penggunaan model pembelajaran Think Pair Share. Subjek penelitian ini adalah siswa kelas 4 SDN Sidorejo Lor 01 Salatiga yang berjumlah 35 siswa. Penelitian dilaksanakan dalam dua siklus, setiap siklus terdiri dari tiga kali pertemuan. Teknik pengumpulan data berupa tes, observasi dan angket. Teknik analisis data menggunakan deskriptif komparatif. Hasil penelitian menunjukkan bahwa motivasi belajar siswa mengalami peningkatan. Pada siklus I, hasil pengamatan menunjukkan bahwa $54 \%$ siswa mencapai motivasi tinggi, sedangkan $46 \%$ siswa berada pada kategori sedang. Pada siklus II, penggunaaan model pembelajaran Think Pair Share disertai perbaikan tindakan yang mendorong siswa untuk lebih aktif dalam pembelajaran. Hasil pengamatan menunjukkan bahwa $83 \%$ siswa mencapai motivasi belajar pada kategori tinggi, sedangkan $17 \%$ siswa berada pada kategori sedang.
\end{abstract}

\begin{abstract}
This type of research is a classroom action research that aims to improve the motivation of learning mathematics grade 4 students SDN Sidorejo Lor 01 through the use of Think Pair Share learning model. The subjects of this research are 4th grade students of SDN Sidorejo Lor 01 Salatiga, which are 35 students. The study was conducted in two cycles, each cycle consisting of three meetings. Data collection techniques such as tests, observations and questionnaires. Data analysis techniques using quantitative descriptive. The results showed that students' learning motivation has increased. In the first cycle, the results showed that $54 \%$ of students achieved high motivation, while $46 \%$ of students were in the medium category. In the second cycle, the use of Think Pair Share learning model is accompanied by improved actions that encourage students to be more active in learning. The results showed that $83 \%$ of students achieved high learning motivation, while $17 \%$ were in the medium category.
\end{abstract}

\section{A. LATAR BELAKANG}

Mata pelajaran Matematika merupakan salah satu mata pelajaran wajib yang harus diberikan kepada siswa pada jenjang pendidikan dasar dan menengah. Matematika adalah produk dari pikiran manusia, utamanya berpusat pada ide-ide, proses, dan pemberian alasan atau penjelasan. Utamanya Matematika merupakan sebuah pola pikir, sebuah jalan, metode pengaturan dari bukti-bukti logis (Yustinus, 2017:1). Matematika sangat penting dan menjadi dasar dalam perkembangan teknologi modern, peran penting dalam berbagai disiplin dan memajukan daya pikir manusia. Untuk menguasai dan mencipta teknologi di masa depan diperlukan penguasaan matematika yang kuat sejak dini.

Mata pelajaran matematika bertujuan agar peserta didik memiliki kemampuan: (1) Memahami konsep matematika, menjelaskan keterkaitan antarkonsep dan mengaplikasikan konsep atau algoritma, secara luwes, akurat, efisien, dan tepat, daam pemecahan masalah, (2) Menggunakan penalaran pada pola dan sifat, melakukan manipulasi matematika dalam membuaut generalisasi, menyusun bukti, atau menjelaskan gagasan dan pernyataan matematika, (3) Memecahkan masalah yang meliputi kemampuan memahami masalah, merancang model matematika, menyelesaikan model dan menafsirkan solusi yang diperoleh, (4) Mengomunikasikan gagasan dengan simbol, tabel, diagram, atau media lain untuk memperjelaskeadaan atau masalah, (5) Memiliki sikap menghargai kegunaan matematika dalam kehidupan, yaitu memiliki rasa ingin tahu, perhatian, dan minat dalam mempelajari matematika, serta sikap ulet dan percaya diri dalam pemecahan masalah (Yustinus, 2017:5-6).

Namun, permasalahan yang terjadi dalam proses pembelajaran Matematika di kelas yaitu kurang antusias siswa dalam proses pembelajaran sehingga kegiatan 
pembelajaran berjalan tidak maksimal. Permasalahan lain adalah strategi penananaman konsep Matematika pada siswa belum sesuai dengan karakteristik masingmasing. Salah satu faktor yang mempengaruhi tingkat pemahaman siswa yaitu adanya motivasi. Menurut Schunk, 1995 dalam (Schunk, Pintrich, \& Meece, 2012) motivasi dapat memengaruhi apa yang kita pelajari, kapan kita belajar, dan bagaimana cara kita belajar.

Hasil wawancara dengan guru kelas 4 SDN Sidorejo Lor 01 Kota Salatiga pada mata pelajaran Matematika, yaitu guru masih kesulitan dalam menanamkan konsep dan mengarahkan siswa untuk memahami dan menyelesaikan sebuah permasalahan matematika mengenai materi bangun datar. Akibatnya ada beberapa siswa yang salah dalam menerima konsep dan bingung memahami materi atau permasalahan yang sudah dijelaskan. Masalah lain dalam proses pembelajaran yaitu ketika siswa mulai bosan mengikuti pembelajaran maka mereka akan sibuk bermain sendiri, mondarmandir dan mengganggu teman lainnya sehingga kelas menjadi ramai. Oleh karena itu diperlukan strategi untuk mengendalikan dan memusatkan perhatian siswa kembali agar suasana tetap kondusif dan berjalan sesuai yang diharapkan. Selain itu, kurangnya motivasi belajar siswa kelas 4 SDN Sidorejo Lor 01 Kota Salatiga juga terlihat dari kurang serius dalam mengerjakan tugas sehingga tugas tidak terselesaikan tepat waktu. Hal ini dikarenakan anak masih belum paham dengan materi yang diajarkan. Kerjasama dalam mengerjakan tugas juga belum ada. Masing-masing siswa masih terkesan individual.

Salah satu model yang sesuai untuk mengatasi permasalahan tersebut adalah dengan menggunakan model pembelajaran Think Pair Share untuk membantu siswa dalam memahami materi yang disampaikan guru. Think Pair Share menurut Frank Lyman dalam (Tampubolon, 2014) berpendapat bahwa model pembelajaran kooperatif TPS adalah pembelajaran yang dilakukan dengan pertukaran pemikiran melalui pengalaman belajar peserta didik.

\section{B. KAJIAN PUSTAKA}

\section{Model Pembelajaran Think Pair Share}

Think Pair Share merupakan salah satu tipe model kooperatif yaitu dengan berkelompok secara pasangan. Think Pair Share (TPS) atau Berpikir Berpasangan Berbagi dikembangkan oleh Frank Lyman dan kawankawannya dari Universitas Maryland. TPS menurut Slavin dalam (Thobroni, 2015) adalah sebuah metode yang sederhana, tetapi sangat berguna yang dikembangkan oleh Frank Lyman dari Universitas Maryland. Ketika guru menerangkan pelajaran di depan kelas, siswa duduk berpasangan dalam kelompoknya. Guru memberikan pertanyaan di kelas. Lalu, siswa diperintahkan untuk memikirkan jawaban, kemudian siswa berpasangan dengan masing-masing pasangannya untuk mencari kesepakatan jawaban. Terakhir guru meminta siswa untuk membagi jawaban kepada seluruh siswa di kelas. Sedangkan menurut Frank Lyman dalam (Tampubolon, 2014) berpendapat bahwa model pembelajaran kooperatif TPS adalah pembelajaran yang dilakukan dengan pertukaran pemikiran melalui pengalaman belajar peserta didik. Selanjutnya Suprijono dalam (Thobroni, 2015) berpendapat bahwa TPS memiliki makna: thinking, siswa diberi kesempatan untuk memikirkan ide-ide mereka tentang pertanyaan atau wacana yang diberikan oleh guru; pairing, siswa menentukan dengan siapa mereka akan berpasangan; sharing, ide-ide yang telah ditemukan dibagikan kepada kelompok lain melalui kegiatan diskusi dan tanya jawab.

Berdasarkan pendapat dari beberapa ahli diatas, dapat disimpulkan bahwa TPS adalah pembelajaran yang mengharuskan siswa untuk berfikir secara individual yang dilanjutkan dengan bertukar pikiran secara berpasangan, dimana hasil ide-ide atau pemecahan masalah dibagikan kepada kelompok lain melalui diskusi.

\section{Langkah-langkah Model Pembelajaran Think Pair Share (TPS)}

Langkah-langkah penggunaan TPS menurut Lyman dan kawan-kawan dalam (Thobroni, 2015) yaitu langkah 1: Berpikir (Thinking), langkah 2: Berpasangan (Pairing), langkah 3: Bebagi (Sharing). Kemudian menurut Miftahul Huda (2014), langkah-langkah model pembelajaran TPS yaitu (1) Siswa ditempatkan dalam kelompok-kelompok. Setiap kelompok terdiri dari empat anggota/siswa, (2) Guru memberikan tugas pada setiap kelompok. (3) Masing-masing kelompok memikirkan dan mengerjakan tugas tersebut sendiri-sendiri terlebih dahulu. (4) Kelompok membentuk anggota-anggotanya secara berpasangan. Setiap pasangan mendiskusikan hasil pengerjaan individu. (5) Kedua pasangan lalu bertemu kembali dalam kelompoknya masing-masing untuk menshare hasil diskusinya. Pendapat serupa juga disampaikan oleh Saur Tampubolon (2014) bahwa langkah-langkah model TPS yaitu (1) Pengelompokkan peserta didik dengan jumlah anggota 5 orang. (2) Pendidik memberikan permasalahan yang dapat dijawab oleh peserta didik dengan mempelajari buku ajar/handout. (3) Pertama peserta didik memikirkan sendiri jawaban permasalahan tersebut, (4) Selanjutnya, peserta didik berbagi pemikiran dalam kelompok, (5) Setelah pekerjaan kelompok tuntas, selanjutnya peserta didik berbagi pemikiran antar kelompok, (6) Peserta didik bersama pendidik menyimpulkan jawaban atas masalah yang diberikan, (7) Penilaian dilakukan untuk mengukur keberhasilan pembelajaran.

Berdasarkan ketiga pendapat para ahli mengenai langkah-langkah model pembelajaran TPS, maka dapat disimpulkan langkah model TPS yaitu (1) Guru memberikan permasalahan terkait dengan pelajaran, (2) Siswa berpikir secara individu mengenai jawaban permasalahan, (3) Masing-masing siswa mengemukakan 
hasil pemikirannya kepada pasangannya, (4) Setiap pasangan menshare hasil diskusi pasangan ke kelompok, (5) Masing-masing kelompok menshare hasilnya ke dalam diskusi kelas (6) Simpulan.

\section{Motivasi}

Motivasi belajar adalah dorongan internal dan eksternal pada peserta didik yang sedang belajar untuk mengadakan perubahan perilaku (Suprijono, 2011). Dorongan intrinsik merupakan dorongan dari dalam diri seseorang yang akan berusaha karena merasa senang melakukan pembelajaran yang baik serta mengalami kepuasan atas hasil belajarnya. Sedangkan dorongan ekstrinsik merupakan dorongan yang timbul oleh rangsangan yang berasal dari luar diri seseorang. Crawford dalam (Tampubolon, 2013) berpendapat bahwa motivasi adalah dorongan yang menimbulkan kemauan pada diri seseorang untuk melakukan sesuatu. Kemudian Sardiman berpendapat bahwa motivasi adalah suatu daya penggerak seseorang untuk melakukan kegiatan dalam mencapai tujuan tertentu. Dari pengertian beberapa ahli diatas, dapat disimpulkan pengertian dari motivasi yaitu dorongan yang timbul baik secara internal maupun eksternal sebagai daya penggerak seseorang untuk melakukan kegiatan dalam mencapai tujuan tertentu.

Motivasi belajar dapat dilihat dari indikatorindikator seperti keantusiasan dalam belajar, minat atau perhatian pada pembelajaran, keterlibatan dalam kegiatan belajar, rasa ingin tahu pada isi pembelajaran, ketekunan dalam belajar, selalu berusaha mencoba, dan aktif mengatasi tantangan yang ada dalam pembelajaran (Wena, 2013). Indikator motivasi belajar menurut Hamzah B. Uno dalam (Suprijono, 2011) dapat diklasifikasikan sebagai berikut: (1) Adanya hasrat dan keinginan berhasil, (2) Adanya dorongan dan kebutuhan dalam belajar, (3) Adanya harapan dan cita-cita masa depan, (4) Adanya penghargaan dalam belajar, (5) Adanya kegiatan yang menarik dalam belajar, (6) Adanya lingkungan belajar yang kondusif sehingga memungkinkan peserta didik dapat belajar dengan baik. Pengukuran motivasi diperlukan untuk mengetahui indikator-indikator motivasi telah tercapai. Ada beberapa metode yang dapat digunakan untuk mengukur motivasi, yaitu observasi langsung, penilaian skala oleh individu lain, dan pelaporan diri. Observasi, menurut Sutrisno Hadi dalam (Sugiyono, 2013) mengemukakan bahwa observasi merupakan suatu proses yang kompleks, tersusun dari berbagai proses biologis dan psikhologis. Dua diantara yang terpenting adalah proses-proses pengamatan dan ingatan. Observasi langsung mengacu pada contoh-contoh perilaku dari pilihan tugas, usaha yang dikeluarkan, dan kegigihan. Penilaian skala oleh Individu lain merupakan penilaian yang dilakukan oleh pengamat terhadap murid pada berbagai karakteristik yang mengindikasikan motivasi. Sedangkan metode pelapor diri merupakan penilaian individu mengenai dirinya sendiri.

\section{METODE PENELITIAN}

Jenis penelitian yang akan dilakukan adalah Penelitian Tindakan Kelas (PTK) sebagai upaya untuk meningkatkan motivasi belajar Matematika siswa. Jenis Penelitian adalah Penelitian Tindakan Kelas (PTK) menggunakan model spiral dari C. Kemmis dan MC. Taggart (1998) dalam penelitian ini menggunakan prosedur penelitian dua siklus yaitu siklus I dan II, dimana setiap siklusnya dilaksanakan dalam tiga kali pertemuan. Masing-masing siklus terdiri dari 4 langkah yaitu perencanaan (planning), pelaksanaan tindakan (acting), observasi (observing) serta refleksi (reflecting). Adapun subyek dalam penelitian ini adalah siswa kelas 4 SDN Sidorejo Lor 01 Salatiga yang berjumlah 35 siswa terdiri dari 17 siswa perempuan dan 18 siswa laki-laki. Penelitian ini memiliki dua variabel yaitu variabel bebas (X) dan variabel terikat (Y). Variabel bebas (X) yang digunakan dalam penelitian ini adalah model pembelajaran Think Pair Share (TPS). Sedangkan variabel terikat $(\mathrm{Y})$ yang digunakan dalam penelitian ini adalah motivasi belajar.

Adapun teknik pengumpulan data pada penelitian ini menggunakan teknik tes dan non tes. Tes adalah cara yang digunakan untuk mengetahui hasil belajar siswa dengan menggunakan model pembelajaran Think Pair Share (TPS). Sedangkan teknik non tes berupa wawancara yaitu tanya jawab yang dilakukan dengan guru kelas IV untuk mengetahui keadaan proses pembelajaran. Selanjutnya ada lembar observasi, yang digunakan untuk mengetahui respon siswa dengan menggunakan pembelajaran Think Pair Share (TPS). Selain observasi, teknik yang digunakan adalah angket yang diisi oleh siswa, satu angket dalam satu siklus. Teknik dokumentasi ini digunakan untuk mengetahui identitas siswa dan karakteristik sekolah. Adapun instrumen pengumpulan data yang digunakan adalah evaluasi dalam bentuk tes, wawancara, lembar observasi dan lembar angket motivasi belajar Matematika.

Indikator kinerja dalam penelitian ini yaitu munculnya motivasi belajar siswa pada mata pelajaran Matematika $75 \%$ dari total siswa dalam kelas lulus kriteria individual.

Teknik analisis data yang digunakan dalam penelitian ini yaitu deskriptif komparatif untuk data kuantitatif yaitu membandingkan nilai tes kondisi awal, nilai tes setelah siklus 1, dan nilai tes setelah siklus 2 . Data motivasi siswa juga dianalisis dengan cara yang sama, yaitu dengan membandingkan skor rata-rata keaktifan siswa pada siklus I dan siklus II. Sedangkan untuk data kualitatif dianalisis menggunakan analisis deskriptif kualitatif berdasarkan hasil observasi dan refleksi dari tiap-tiap siklus. 


\section{HASIL DAN PEMBAHASAN}

1. Deskripsi Kondisi Awal

Berdasarkan kegiatan wawancara terhadap guru kelas 4 SDN Sidorejo Lor 01, diperoleh keterangan bahwa sebagian besar siswa kelas 4 mengalami kesulitan belajar pada mata pelajaran Matematika. Berdasarkan data hasil belajar Matematika yang diperoleh dari 35 siswa kelas 4 diketahui sebagai:

\section{TABEL 1}

HASIL BELAJAR MATEMATIKA SISWA KELAS 4 SDN SIDOREJO LOR O1 SALATIGA PADA KONDISI AWAL

\begin{tabular}{|l|l|l|l|}
\hline No & $\begin{array}{c}\text { Interval } \\
\text { Nilai }\end{array}$ & Frekuensi & $\begin{array}{c}\text { Presentase } \\
\text { (\%) }\end{array}$ \\
\hline 1. & $15-28$ & 2 & 6 \\
\hline 2. & $29-42$ & 8 & 23 \\
\hline 3. & $43-56$ & 4 & 11 \\
\hline $4 \cdot$ & $57-70$ & 6 & 17 \\
\hline 5. & $71-84$ & 8 & 23 \\
\hline 6. & $85-100$ & 7 & 20 \\
\hline Jumlah & 35 \\
\hline \multicolumn{2}{|l|}{ Rata-Rata } & 61 \\
\hline \multicolumn{2}{|l|}{ Nilai Tertinggi } & 100 \\
\hline \multicolumn{2}{|l}{ Nilai Terendah } & 15 \\
\hline
\end{tabular}

Berdasarkan tabel 1 dapat diuraikan bahwa hasil belajar siswa sebelum dilakukan tindakan pada mata pelajaran Matematika terdapat 2 siswa berada pada interval nilai $15-28$ dengan presentase $6 \%, 8$ siswa berada pada interval nilai 29-42 dengan presentase $23 \%$, 4 siswa berada pada interval nilai 43-56 dengan presentase 11\%, 6 siswa berada pada interval nilai 57-70 dengan presentase $17 \%, 8$ siswa berada pada interval nilai 71-84 dengan presentase 23\%, dan 7 siswa berada pada interval nilai 85-100 dengan presentase $20 \%$.

Berdasarkan KKM (Kriteria Ketuntasan Minimal) yang telah ditentukan oleh sekolah yaitu 70, maka dapat dilihat siswa yang tuntas maupun bellum tuntas sebagai berikut:

TABEL 2

KETUNTASAN HASIL BELAJAR MATEMATIKA SISWA KELAS 4 SDN SIDOREJO LOR 01 SALATIGA PADA KONDISI AWAL

\begin{tabular}{|l|l|l|l|l|}
\hline No & Ketuntasan & Nilai & Frekuensi & $\begin{array}{c}\text { Presentase } \\
\text { (\%) }\end{array}$ \\
\hline 1 & Tuntas & $\geq 70$ & 15 & 43 \\
\hline 2 & $\begin{array}{l}\text { Belum } \\
\text { Tuntas }\end{array}$ & $<70$ & 20 & 57 \\
\hline \multicolumn{2}{|l|}{ Jumlah } & 35 & 100 \\
\hline
\end{tabular}

Berdasarkan tabel 2 dapat diketahui bahwa siswa yang belum tuntas dengan nilai kurang dari 70 berjumlah lebih banyak dari siswa yang belum tuntas yaitu 20 siswa atau $57 \%$ dari total keseluhan siswa sedangkan siswa yang sudah tuntas berjumlah 15 orang atau $43 \%$ dari total keseluruhan siswa dengan nilai lebih dari sama dengan 70 .

\section{SIKLUS 1}

Siklus I terdiri dari 4 tahap yaitu perencanaan, pelaksanaan tindakan, observasi dan refleksi. Pelaksanaan tindakan dilakukan dalam tiga kali pertemuan. Pada pertemuan pertama dan kedua dilakukan observasi aktivitas guru maupun siswa serta pada pertemuan ketiga dilakukan evaluasi soal dan pengisian angket motivasi belajar untuk mengukur seberapa tinggi motivasi belajar yang dimiliki siswa. Motivasi diukur menggunakan skala Likert yang terdiri 3 kategori yaitu tinggi, sedang dan rendah. Berikut hasil pelaksanaan tindakan siklus I dengan menggunakan model pembelajaran Think Pair Share:

TABEL 3

MOTIVASI BELAJAR MATEMATIKA SISWA KELAS IV SDN SIDOREJO LOR 01 SALATIGA PADA SIKLUS I

\begin{tabular}{|c|c|c|c|c|}
\hline No & $\begin{array}{c}\text { Nilai } \\
\text { Motivasi } \\
\text { Belajar }\end{array}$ & Kriteria & $\begin{array}{c}\text { Jumlah } \\
\text { Siswa }\end{array}$ & $\begin{array}{c}\text { Presentase } \\
\text { (\%) }\end{array}$ \\
\hline 1 & $\leq 59$ & Rendah & - & - \\
\hline 2 & $60-79$ & Sedang & 16 & 46 \\
\hline 3 & $\geq 80$ & Tinggi & 19 & 54 \\
\hline \multicolumn{3}{|c|}{ Jumlah } & 35 & 100 \\
\hline \multicolumn{3}{|c|}{ Rata-Rata } & \multicolumn{2}{|l|}{79} \\
\hline \multicolumn{3}{|c|}{ Tertinggi } & \multicolumn{2}{|l|}{95} \\
\hline \multicolumn{3}{|c|}{ Terendah } & \multicolumn{2}{|l|}{65} \\
\hline
\end{tabular}

Berdasarkan tabel 3 diketahui bahwa hasil motivasi belajar Matematika siswa kelas 4 SDN Sidorejo Lor 01 Salatiga pada siklus 1, jumlah siswa yang berada pada kriteria sedang berjumlah 16 siswa atau 46\% dari keseluruhan siswa. Sedangkan jumlah siswa yang berada pada kriteria tinggi berjumlah 19 siswa atau 54\% dari keseluruhan siswa. Rata-rata yang diperoleh untuk motivasi belajar pada siklus I yaitu 79 dimana masih berada pada kriteria motivasi sedang sehingga perlu ditingkatkan lagi.

TABEL 4

HASIL BELAJAR MATEMATIKA SISWA KELAS 4 SDN SIDOREJO LOR 01 SALATIGA PADA SIKLUS I

\begin{tabular}{|l|l|l|l|}
\hline No & Interval & Frekuensi & $\begin{array}{c}\text { Presentase } \\
\text { (\%) }\end{array}$ \\
\hline 1 & $40-49$ & 3 & 9 \\
\hline 2 & $50-59$ & 3 & 9 \\
\hline 3 & $60-69$ & 7 & 20 \\
\hline 4 & $70-79$ & 7 & 20 \\
\hline 5 & $80-89$ & 6 & 17 \\
\hline 6 & $90-100$ & 9 & 26 \\
\hline Jumlah & 35 & 100 \\
\hline Rata-rata & 74 & \\
\hline Nilai Tertinggi & 100 & \\
\hline $\begin{array}{l}\text { Nilai } \\
\text { Terendah }\end{array}$ & 40 \\
\hline
\end{tabular}

Berdasarkan tabel 4 diketahui hasil belajar Matematika siswa kelas 4 SDN Sidorejo Lor 01 Salatiga pada siklus I sudah mengalami peningkatan, hal ini 
dapat dilihat banyaknya siswa yang mendapat rentang nilai 40-49 sebanyak 3 siswa atau 9\% dari keseluruhan siswa, siswa yang mendapat rentang nilai 50-59 sebanyak 3 siswa atau $9 \%$ dari keseluruhan siswa, siswa yang mendapat rentang nilai 60-69 sebanyak 7 siswa atau 20\% dari keseluruhan siswa, siswa yang mendapatkan rentang nilai 70-79 sebanyak 7 siswa atau 20\% dari keseluruhan siswa, siswa yang mendapatkan rentang nilai 80-89 ada 6 siswa atau $17 \%$ dari keseluruhan siswa, dan ada 9 siswa atau 26\% dari keseluruhan siswa yang mendapat rentang nilai 90-100. Nilai rata-rata juga mengalami peningkatan yaitu 74 dengan nilai tertinggi adalah 100 sedangkan nilai terendah adalah 40 .

Ketuntasan hasil belajar siswa kelas 4 SDN Sidorejo Lor 01 Salatiga dapat dilihat sebagai berikut:

TABEL 5

KETUNTASAN HASIL BELAJAR MATEMATIKA SISWA KELAS 4 SDN SIDOREJO LOR 01 SALATIGA PADA SIKLUS I

\begin{tabular}{|l|l|c|c|}
\hline No & Ketuntasan & Frekuensi & Presentase \\
\hline $\mathbf{1}$ & Tuntas & $\mathbf{2 2}$ & 63 \\
\hline $\mathbf{2}$ & Tidak Tuntas & 13 & 37 \\
\hline & Rata-Rata & \multicolumn{2}{|c|}{74} \\
\hline & Tertinggi & \multicolumn{2}{|c|}{100} \\
\hline & Terendah & \multicolumn{2}{|c|}{40} \\
\hline
\end{tabular}

Berdasarkan tabel 5 diketahui bahwa jumlah siswa tuntas sebanyak 22 siswa atau 63\% dari keseluruhan siswa, sedangkan jumlah siswa yang tidak tuntas sebanyak 13 siswa atau 37\% dari keseluruhan siswa. Rata-rata hasil belajar pada siklus I yaitu 74 dengan nilai tertinggi 100 dan nilai terendah 40.

Selama pelaksanaan tindakan telah dilakukan pengamatan atau observasi terhadap tindakan guru dan aktivitas siswa yang dapat dilihat sebagai berikut: TABEL 6

HASIL OBSERVASI TINDAKAN GURU DALAM MENERAPKAN MODEL PEMBELAJARAN THINK PAIR SHARE DI SDN SIDOREJO LOR 01 SALATIGA

TAHUN PELAJARAN 2017/2018

\begin{tabular}{|c|c|c|c|c|c|c|c|}
\hline \multirow[t]{2}{*}{ No } & \multirow{2}{*}{$\begin{array}{c}\text { Aspek } \\
\text { yang } \\
\text { diamati }\end{array}$} & \multicolumn{2}{|c|}{\begin{tabular}{c|} 
Indikator \\
Pengamatan
\end{tabular}} & \multicolumn{2}{|c|}{$\begin{array}{c}\text { Pertemuan } \\
1\end{array}$} & \multicolumn{2}{|c|}{$\begin{array}{c}\text { Pertemuan } \\
2\end{array}$} \\
\hline & & Jml & $\%$ & Jml & $\%$ & Jml & $\%$ \\
\hline 1. & $\begin{array}{l}\text { Kegiata } \\
\text { n Awal }\end{array}$ & 4 & 24 & 4 & 24 & 3 & 18 \\
\hline 2. & $\begin{array}{l}\text { Kegiata } \\
\text { n Inti }\end{array}$ & 9 & 53 & 7 & 41 & 9 & 53 \\
\hline 3. & $\begin{array}{l}\text { Kegiata } \\
\mathrm{n} \\
\text { Penutup }\end{array}$ & 4 & 24 & 4 & 24 & 4 & 24 \\
\hline \multicolumn{2}{|c|}{ Jumlah } & 17 & $100 \%$ & 15 & $89 \%$ & 16 & $95 \%$ \\
\hline
\end{tabular}

Berdasarkan tabel 6 hasil observasi tindakan guru selama pelaksanaan siklus 1 dengan menggunakan model Think Pair Share pada pertemuan 1 jumlahnya 15 atau $89 \%$ dari keseluruhan indikator yang terlaksana.
Sedangkan pada pertemuan 2 jumlahnya 16 atau 95\% dari keseluruhan indikator yang terlaksana. Jadi dapat diketahui bahwa pelaksanaan siklus 1 pertemuan 1 sudah berjalan dengan baik, namun masih ada beberapa kekurangan yaitu belum terlaksanya kegiatan diskusi yang melibatkan semua siswa untuk aktif. Sedangkan pada pertemuan kedua sudah baik namun masih ada kekurangan dimana guru kurang memotivasi siswa untuk tanya jawab.

Hasil observasi aktivitas siswa pada siklus I pertemuan 1 dan pertemuan 2 dengan aktivitas guru menggunakan model pembelajaran Think Pair Share pada mata pelajaran Matematika dapat dilihat sebagai berikut:

TABEL 7

HASIL OBSERVASI AKTIVITAS SISWA DALAM MENERAPKAN MODEL PEMBELAJARAN THINK

PAIR SHARE DI SDN SIDOREJO LOR 01 SALATIGA TAHUN PELAJARN 2017/2018

\begin{tabular}{|c|c|c|c|c|c|c|c|}
\hline \multirow[t]{2}{*}{$\begin{array}{l}\mathbf{N} \\
\mathbf{o}\end{array}$} & \multirow{2}{*}{$\begin{array}{c}\text { Aspek } \\
\text { yang } \\
\text { diamati }\end{array}$} & \multicolumn{2}{|c|}{$\begin{array}{c}\text { Indikator } \\
\text { Pengamatan }\end{array}$} & \multicolumn{2}{|c|}{ Pertemuan 1} & \multicolumn{2}{|c|}{$\begin{array}{c}\text { Pertemuan } \\
2\end{array}$} \\
\hline & & Jml & $\%$ & Jml & $\%$ & Jml & $\%$ \\
\hline 1. & $\begin{array}{l}\text { Kegiatan } \\
\text { Awal }\end{array}$ & 4 & 24 & 4 & 24 & 3 & 24 \\
\hline 2. & $\begin{array}{l}\text { Kegiatan } \\
\text { Inti }\end{array}$ & 9 & 53 & 6 & 41 & 9 & 47 \\
\hline 3 . & $\begin{array}{l}\text { Kegiatan } \\
\text { Penutup }\end{array}$ & 4 & 24 & 4 & 24 & 4 & 24 \\
\hline \multicolumn{2}{|c|}{ Jumlah } & 17 & $100 \%$ & 15 & $89 \%$ & 16 & $95 \%$ \\
\hline
\end{tabular}

Berdasarkan tabel 7 diketahui bahwa pada pertemuan 1 telah telaksana 15 atau $89 \%$ dari keseluruhan indikator telah terlaksana. Sedangkan pada pertemuan kedua 16 atau 96\% dari keseluruhan indikator telah terlaksana dengan baik. Aktivitas siswa telah berjalan dengan baik namun masih ada kekurangan yaitu siswa belum terlibat aktif dalam diskusi kelompok serta pada pertemuan kedua perlu ditingkatkan motivasi dalam mengikuti pembelajaran.

\section{SIKLUS II}

Siklus II penggunaan model pembelajaran Think Pair Share untuk peningkatan motivasi belajar dilakukan setelah siklus 1 dan dilakukan perbaikanperbaikan melalui kegiatan refleksi untuk meningkatkan motivasi belajar siswa. Siklus 2 dilakukan dalam 3 kali pertemuan seperti pada siklus 1. Pada pertemuan pertama dan kedua dilakukan observasi terhadap tindakan guru dan siswa sedangkan pada pertemuan ketiga dilakukan evaluasi dengan memberikan tes serta membagikan lembar angket motivasi untuk mengetahui tingkat motivasi belajar siswa. Hasil total perhitungan angket motivasi belajar siswa dapat dilihat pada tabel 8 sebagai berikut: 
TABEL 8

MOTIVASI BELAJAR MATEMATIKA SISWA KELAS 4 SDN SIDOREJO LOR 01 SALATIGA PADA SIKLUS II

\begin{tabular}{|l|l|l|l|l|}
\hline No & $\begin{array}{c}\text { Nilai } \\
\text { Motivasi } \\
\text { Belajar }\end{array}$ & Kriteria & $\begin{array}{c}\text { Jumlah } \\
\text { Siswa }\end{array}$ & $\begin{array}{c}\text { Presentase } \\
\text { (\%) }\end{array}$ \\
\hline $\mathbf{1}$ & $\leq 59$ & Rendah & - & - \\
\hline $\mathbf{2}$ & $60-79$ & Sedang & 6 & 17 \\
\hline 3 & $\geq 80$ & Tinggi & 29 & 83 \\
\hline Jumlah & 35 & 100 \\
\hline \multicolumn{2}{|l|}{ Rata-Rata } & 84 \\
\hline \multicolumn{2}{|l|}{ Tertinggi } & 96 \\
\hline \multicolumn{2}{|l|}{ Terendah } & 67 \\
\hline
\end{tabular}

Berdasarkan tabel 8 diketahui hasil motivasi belajar Matematika siswa kelas 4 SDN Sidorejo Lor 01 Salatiga pada siklus II, jumlah siswa yang berada pada kriteria sedang berjumlah 6 siswa atau $17 \%$ dari keseluruhan siswa. Sedangkan jumlah siswa yang berada pada kriteria tinggi berjumlah 29 siswa atau 83\% dari keseluruhan siswa. Rata-rata yang diperoleh untuk motivasi belajar pada siklus II yaitu 84 dimana telah terjadi peningkatan dari siklus I dan sudah berada pada kriteria motivasi tinggi.

Evaluasi yang dilakukan pada akhir siklus II dengan menggunakan model pembelajaran Think Pair Share materi luas dan keliling bangun datar telah mengalami peningkatan sebagai berikut:

TABEL 9

HASIL BELAJAR MATEMATIKA SISWA KELAS 4 SDN SIDOREJO LOR 01 SALATIGA PADA SIKLUS II

\begin{tabular}{|l|l|l|l|}
\hline No & Interval & Frekuensi & $\begin{array}{c}\text { Presentase } \\
\text { (\%) }\end{array}$ \\
\hline 1 & $63-68$ & 6 & 17 \\
\hline 2 & $69-74$ & 12 & 34 \\
\hline 3 & $75-80$ & 8 & 23 \\
\hline 4 & $81-86$ & 0 & 0 \\
\hline 5 & $87-92$ & 0 & 07 \\
\hline 6 & $93-100$ & 9 & 26 \\
\hline Jumlah & 35 & 100 \\
\hline Rata-rata & 79 & \\
\hline Nilai Tertinggi & 100 \\
\hline Nilai Terendah & 63 \\
\hline
\end{tabular}

Berdasarkan tabel 9 diketahui hasil belajar Matematika siswa kelas 4 SDN Sidorejo Lor 01 Salatiga pada siklus II melalui penggunaan model pembelajaran Think Pair Share telah mengalami peningkatan, hal ini dapat dilihat banyaknya siswa yang mendapat interval nilai 63-68 sebanyak 6 siswa atau 17\% dari keseluruhan siswa, siswa yang mendapat interval nilai 69-74 sebanyak 12 siswa atau 34\% dari keseluruhan siswa, siswa yang mendapat interval nilai $75-80$ sebanyak 8 siswa atau $23 \%$ dari keseluruhan siswa, siswa yang mendapatkan interval nilai 81-86 dan 87-92 sebanyak o siswa atau $0 \%$ dari keseluruhan siswa dan siswa yang mendapatkan interval nilai 93-100 ada 9 siswa atau $26 \%$ dari keseluruhan siswa. Nilai rata-rata pada siklus II mengalami peningkatan yaitu 79 dengan nilai tertinggi adalah 100 sedangkan nilai terendah adalah 63 . Ketuntasan siswa dapat dilihat pada tabel 10 sebagai berikut:

TABEL 10

KETUNTASAN HASIL BELAJAR MATEMATIKA SIKLUS II SISWA KELAS IV SDN SIDOREJO LOR 01 SALATIGA SEMESTER 2/2017-2018

\begin{tabular}{|l|l|l|l|}
\hline No & Ketuntasan & Frekuensi & Presentase \\
\hline $\mathbf{1}$ & Tuntas & $\mathbf{2 9}$ & 83 \\
\hline $\mathbf{2}$ & Tidak Tuntas & 6 & 17 \\
\hline & Rata-Rata & 79 & \multicolumn{2}{|l|}{} \\
\hline & Maksimun & 100 \\
\hline & Minimun & 63 & \multicolumn{2}{l|}{} \\
\hline
\end{tabular}

Berdasarkan tabel 10 Dapat diketahui hasil belajar dalam pembelajaran Matematika menggunakan model pembelajaran Think Pair Share dari siklus II ada 29 siswa atau $83 \%$ dari keseluruhan siswa yang tuntas dan 6 siswa atau 17\% dari keseluruhan siswa yang tidak tuntas. Rata-rata nilai yang diperoleh dari siklus II yaitu 79, dengan nilai maksimum 100 dan nilai minimun 63.

Selama pelaksanaan tindakan siklus II telah dilakukan observasi tindakan guru sesuai langkahlangkah model pembelajaran Think Pair Share yang dapat dilihat pada tabel 11 sebagai berikut:

TABEL 11

HASIL OBSERVASI TINDAKAN GURU DALAM MENERAPKAN MODEL PEMBELAJARAN THINK PAIR SHARE DI SDN SIDOREJO LOR 01 SALATIGA TAHUN PELAJARN 2017/2018

\begin{tabular}{|c|c|c|c|c|c|c|c|}
\hline \multirow[t]{2}{*}{ No } & \multirow{2}{*}{$\begin{array}{c}\text { Aspek } \\
\text { yang } \\
\text { diamati }\end{array}$} & \multicolumn{2}{|c|}{$\begin{array}{c}\text { Indikator } \\
\text { Pengamatan }\end{array}$} & \multicolumn{2}{|c|}{$\begin{array}{c}\text { Pertemuan } \\
1 \\
\end{array}$} & \multicolumn{2}{|c|}{$\begin{array}{c}\text { Pertemuan } \\
2\end{array}$} \\
\hline & & Jml & $\%$ & Jml & $\%$ & Jml & \% \\
\hline 1. & $\begin{array}{l}\text { Kegiata } \\
\text { n Awal }\end{array}$ & 4 & 24 & 4 & 24 & 4 & 24 \\
\hline 2. & $\begin{array}{l}\text { Kegiata } \\
\text { n Inti }\end{array}$ & 9 & 53 & 9 & 53 & 9 & 53 \\
\hline 3. & $\begin{array}{l}\text { Kegiata } \\
\mathrm{n} \\
\text { Penutup }\end{array}$ & 4 & 24 & 4 & 24 & 4 & 24 \\
\hline \multicolumn{2}{|c|}{ Jumlah } & 17 & $100 \%$ & 17 & $100 \%$ & 17 & $100 \%$ \\
\hline
\end{tabular}

Berdasarkan tabel 11 baik pada pertemuan 1 maupun pertemuan 2 pada siklus II dalam penggunaan model pembelajaran Think Pair Share telah dilakukan semua sesuai indikator yang telah ditentukan sehingga presentase $100 \%$.

Selama pelaksanaan siklus II observasi juga dilakukan untuk mengamati aktivitas siswa dalam mengikuti pembelajaran yang dapat dilihat pada tabel 12 sebagai berikut: 
TABEL 12

HASIL OBSERVASI AKTIVITAS SISWA DALAM MENERAPKAN MODEL PEMBELAJARAN THINK PAIR SHARE DI SDN SIDOREJO LOR O1 SALATIGA TAHUN PELAJARN 2017/2018

\begin{tabular}{|c|c|c|c|c|c|c|c|}
\hline \multirow[t]{2}{*}{ No } & \multirow{2}{*}{$\begin{array}{c}\text { Aspek } \\
\text { yang } \\
\text { diamati }\end{array}$} & \multicolumn{2}{|c|}{\begin{tabular}{c|} 
Indikator \\
Pengamatan
\end{tabular}} & \multicolumn{2}{|c|}{$\begin{array}{c}\text { Pertemuan } \\
1\end{array}$} & \multicolumn{2}{|c|}{$\begin{array}{c}\text { Pertemuan } \\
2 \\
\end{array}$} \\
\hline & & Jml & $\%$ & Jml & $\%$ & Jml & $\%$ \\
\hline 1. & $\begin{array}{l}\text { Kegiata } \\
\mathrm{n} \text { Awal }\end{array}$ & 4 & 24 & 4 & 24 & 4 & 24 \\
\hline 2 & $\begin{array}{l}\text { Kegiata } \\
\text { n Inti }\end{array}$ & 9 & 53 & 9 & 53 & 9 & 53 \\
\hline 3 & $\begin{array}{l}\text { Kegiata } \\
\text { n } \\
\text { Penutup }\end{array}$ & 4 & 24 & 4 & 24 & 4 & 24 \\
\hline \multicolumn{2}{|c|}{ Jumlah } & 17 & $100 \%$ & 17 & $100 \%$ & 17 & $100 \%$ \\
\hline
\end{tabular}

Berdasarkan tabel 12 diketahui bahwa hasil observasi aktivitas siswa dalam penerapan model Think Pair Share siklus II pada pertemuan pertama telah melaksanakan semua indikator yaitu 17 atau $100 \%$ dari keseluruhan indikator, begitupula dengan pertemuan kedua semua indikator aktivitas siswa telah terlaksana 17 atau $100 \%$ dari keseluruhan indikator. Oleh karena itu pembelajaran telah berjalan dengan baik sesuai tujuan pembelajaran.

\section{Analisis Perbandingan Aktivitas Guru}

Analisis data aktivitas guru mulai penelitian siklus I hingga siklus II yang dilaksanakan peneliti dengan menggunakan model pembelajaran Think Pair Share hasilnya dapat dilihat pada tabel 13 sebagai berikut:

TABEL 13

PERBANDINGAN AKTIVITAS GURU DALAM PEMBELAJARAN MATEMATIKA MENGGUNAKAN MODEL PEMBELAJARAN THINK PAIR SHARE PADA SIKLUS I DAN SIKLUS II

\begin{tabular}{|l|l|l|l|l|l|}
\hline No & $\begin{array}{c}\text { Aktivitas } \\
\text { Guru }\end{array}$ & \multicolumn{2}{|c|}{ Siklus I } & \multicolumn{2}{c|}{ Siklus II } \\
\hline & & $\begin{array}{c}\text { Perte- } \\
\text { muan } \\
\text { Pertama }\end{array}$ & $\begin{array}{c}\text { Perte- } \\
\text { muan } \\
\text { Kedua }\end{array}$ & $\begin{array}{c}\text { Perte- } \\
\text { muan } \\
\text { Pertama }\end{array}$ & $\begin{array}{c}\text { Perte- } \\
\text { muan } \\
\text { Kedua }\end{array}$ \\
\hline 1 & Dilakukan & 15 & 16 & 17 & 17 \\
\hline 2 & $\begin{array}{l}\text { Tidak } \\
\text { Dilakukan }\end{array}$ & 2 & 1 & 0 & 0 \\
\hline \multicolumn{2}{|l}{ Jumlah } & 17 & 17 & 17 & 17 \\
\hline
\end{tabular}

Berdasarkan tabel 13 diatas terdapat perbaikan aktivitas guru dalam menerapkan model pembelajaran Think Pair Share, dari pertemuan pertama siklus I guru hanya melakukan 15 tindakan, tindakan yang tidak dilakukan adalah indikator nomor 12 yaitu guru memberikan kesempatan kepada siswa untuk memberikan masukan atau saran terhadap kelompok lain yang maju dan indikator nomor 13 yaitu guru memberikan penghargaan atas hasil yang dicapai siswa. Sedangkan pada pertemuan kedua siklus I guru telah melakukan 16 tindakan, hanya satu tindakan yang belum dilakukan yaitu guru menyampaikan motivasi pada siswa. Pada siklus II pada pertemuan pertama dan kedua semua tindakan yaitu 17 indikator telah dilakukan dengan baik.

\section{Analisis Perbandingan Aktivitas Siswa dalam Pembelajaran}

Hasil analisis data aktivitas siswa mulai penelitian siklus I dan siklus II yang dilaksanakan peneliti dengan menggunakan model pembelajaran Think Pair Share. Dapat dilihat siklus II aktivitas siswa ada peningkatan pernyataaan langkah-langkah 17 item sudah dilakukan dari pertemuan I dan pertemuan II. Lebih jelas dapat dilihat perbandingan siklus I dan siklus II pada tabel 14 sebagai berikut :

TABEL 14

PERBANDINGAN AKTIVITAS SISWA DALAM

PEMBELAJARAN MATEMATIKA MENGGUNAKAN MODEL PMBELAJARAN THINK PAIR SHARE PADA SIKLUS I DAN SIKLUS II

\begin{tabular}{|l|l|l|l|l|l|}
\hline No & $\begin{array}{c}\text { Aktivitas } \\
\text { Guru }\end{array}$ & \multicolumn{2}{|c|}{ Siklus I } & \multicolumn{2}{c|}{ Siklus II } \\
\hline & & $\begin{array}{l}\text { Perte- } \\
\text { muan } \\
\text { Pertama }\end{array}$ & $\begin{array}{l}\text { Perte- } \\
\text { muan } \\
\text { Kedua }\end{array}$ & $\begin{array}{l}\text { Perte- } \\
\text { muan } \\
\text { Pertama }\end{array}$ & $\begin{array}{l}\text { Perte- } \\
\text { muan } \\
\text { Kedua }\end{array}$ \\
\hline 1 & Dilakukan & 14 & 16 & 17 & 17 \\
\hline 2 & $\begin{array}{l}\text { Tidak } \\
\text { Dilakukan }\end{array}$ & 3 & 1 & 0 & 0 \\
\hline Jumlah & 17 & 17 & 17 & 17 \\
\hline
\end{tabular}

Berdasarkan tabel 14 terdapat peningkatan aktivitas siswa dalam pembelajaran Matematika menggunakan model pembelajaran Think Pair Share, dari pertemuan pertama siklus I siswa hanya melakukan 14 tindakan sedangkan tindakan yang belum dilakukan adalah indikator nomor 11 yaitu siswa berbagi dengan kelompok pasangan lain untuk menyelesaikan permasalahan, indikator nomor 12 yaitu siswa memberikan masukan atau saran terhadap kelompok lain yang sedang maju kedepan dan indikator nomor 13 siswa mengerjakan tes evaluasi dengan semangat. Pada pertemuan kedua siklus I siswa telah melakukan 16 tindakan, hanya satu tindakan yang belum dilakukan yaitu siswa menerima motivasi yang diberikan oleh guru. Pada siklus II pada pertemuan pertama dan kedua semua tindakan telah dilakukan dengan baik.

\section{Analisis Komparatif Motivasi Belajar Siswa}

Berdasarkan hasil tindakan yang telah dilakukan terjadi peningkatan motivasi belajar siswa melalui model pembelajaran Think Pair Share pada mata pelajaran Matematika dengan pokok bahasan bangun datar siswa kelas 4 SDN Sidorejo Lor 01 Salatiga pada semester 2 tahun ajaran 2017/2018. Keberhasilan tersebut dapat dilihat pada tabel 15 analisis komparatif motivasi belajar siswa sebagai berikut: 
TABEL 15

ANALISIS KOMPARATIF MOTIVASI BELAJAR

MATEMATIKA SIKLUS I DAN SIKLUS II SISWA KELAS 4 SDN SIDOREJO LOR 01 SALATIGA SEMESTER 2/2017-2018

\begin{tabular}{|l|l|l|l|l|}
\hline \multirow{2}{*}{ Kriteria } & \multicolumn{2}{|c|}{ Siklus I } & \multicolumn{2}{c|}{ Siklus II } \\
\cline { 2 - 5 } & Frekuensi & \% & Frekuensi & \% \\
\hline $\begin{array}{l}\text { Motivasi } \\
\text { Tinggi }\end{array}$ & 19 & 54 & 29 & 83 \\
\hline $\begin{array}{l}\text { Motivasi } \\
\text { Sedang }\end{array}$ & 16 & 46 & 6 & 17 \\
\hline $\begin{array}{l}\text { Motivasi } \\
\text { Rendah }\end{array}$ & - & - & - & - \\
\hline Jumlah & 35 & 100 & 35 & 100 \\
\hline
\end{tabular}

Berdasarkan tabel 15 perbandingan motivasi belajar Matematika pada siklus I dan II yang menempati kriteria motivasi tinggi pada siklus I yaitu 19 siswa atau $54 \%$ dan pada siklus II yaitu 29 siswa atau $83 \%$ siswa dikatakan menduduki tingkat motivasi tinggi atau hampir seluruh siswa dikatakan termotivasi dengan baik dalam pembelajaran. Disini terdapat kenaikan antara siklus I ke siklus II yaitu 29\%. Sedangkan pada kriteria motivasi sedang dari siklus I yang semula 16 siswa atau 46\% menjadi 6 siswa atau $17 \%$. Berdasarkan hasil tersebut maka tindakan penelitian menggunakan model pembelajaran Think Pair terbukti dapat meningkatkan motivasi belajar dan telah mencapai indikator keberhasilan yang ditentukan yaitu $75 \%$ siswa mencapai ketuntasan belajar.

\section{Analisis Komparatif Hasil Belajar Siswa}

Setelah dilakukan pembelajaran dengan menggunakan model Think Pair Share dapat diketahui hasil belajar Matematika siswa kelas 4 SDN Sidorejo Lor o1 Salatiga mengalami peningkatan dari kondisi awal atau pra siklus, siklus I dan siklus II, peningkatan tersebut dapat dilihat pada tabel 15 berikut ini:

TABEL 16

ANALISIS KOMPARATIF KETUNTASAN HASIL BELAJAR MATEMATIKA SISWA KELAS 4 SDN SIDOREJO LOR 01 SALATIGA

SEMESTER 2/2017-2018

\begin{tabular}{|l|l|c|c|c|c|c|c|}
\hline \multirow{2}{*}{ No } & \multirow{2}{*}{ Ketuntasan } & \multicolumn{2}{|c|}{$\begin{array}{c}\text { Pra } \\
\text { Siklus }\end{array}$} & \multicolumn{2}{|c|}{ Siklus } & \multicolumn{2}{|c|}{ Siklus } \\
\cline { 3 - 8 } & & $\mathbf{f}$ & $\mathbf{\%}$ & $\mathbf{f}$ & $\mathbf{\%}$ & $\mathbf{f}$ & $\mathbf{\%}$ \\
\hline $\mathbf{1}$ & Tuntas & $\mathbf{2 0}$ & 57 & $\mathbf{2 2}$ & 63 & $\mathbf{2 9}$ & 83 \\
\hline $\mathbf{2}$ & Tidak Tuntas & $\mathbf{1 5}$ & 43 & 13 & 37 & 6 & 17 \\
\hline & Rata-Rata & 61 & 74 & & 79 & \\
\hline & Maksimun & 100 & 100 & \multicolumn{2}{|l|}{100} & \\
\hline & Minimun & 15 & 40 & 63 \\
\hline
\end{tabular}

Berdasarkan data tabel 16 dapat dilihat terjadi peningkatan hasil belajar siswa dari kondisi awal, ke siklus I dan siklus II. Dari 20 siswa atau 57\% dari keseluruhan siswa yang tuntas pada kondisi awal meningkat menjadi 22 siswa atau 63\% dari keseluruhan siswa yang tuntas dan pada siklus II meningkat lagi menjadi 29 siswa atau $83 \%$ siswa sudah tuntas. Berdasarkan hasil tersebut maka tindakan penelitian menggunakan model pembelajaran Think Pair terbukti dapat meningkatkan motivasi belajar yang ditandai pula dengan meningkatnya hasil belajar siswa.

\section{Pembahasan}

Sebelum dilakukan tindakan, siswa yang tuntas belajar adalah 20 siswa (57\%) dari 35 siswa. Setelah diberikan tindakan pada siklus I, terjadi pertambahan siswa yang tuntas menjadi 22 siswa (63\%). Setelah diberikan tindakan pada siklus II, terjadi lagi peningkatan ketuntasan belajar siswa menjadi 29 siswa (83\%). Siswa yang belum tuntas sebelum diberikan tindakan adalah 15 siswa (43\%). Setelah diberikan tindakan pada siklus I, terjadi penurunan menjadi 13 siswa (37\%). Setelah diberikan tindakan pada siklus II, terjadi lagi penurunan menjadi 6 siswa (17\%) yang belum tuntas.

Selain meningkatkan hasil belajar Matematika, hasil penelitian ini juga membuktikan bahwa menggunakan pembelajaran Think Pair Share (TPS), mampu meningkatkan motivasi belajar siswa. Hal ini dibuktikan dengan adanya peningkatan motivasi melalui angket, pada siklus I motivasi belajar siswa dalam mengikuti pembelajaran dengan pembelajaran Think Pair Share (TPS) berada pada kategori sedang dengan nilai ratarata 79,4. setelah dilaksanakan perbaikan-perbaikan kinerja pada siklus II, terjadi peningkatan motivasi belajar dalam mengikuti pembelajaran Think Pair Share (TPS) berada pada kategori tinggi dengan nilai rata-rata 84,4 .

Penerapan model Think Pair Share membuat pembelajaran lebih menyenangkan karena pembelajaran yang dilakukan mendorong siswa untuk lebih aktif baik secara individu maupun secara kelompok dengan bertukar pikiran sehingga lebih dimengerti bagi mereka karena penjelasan diperoleh dari teman sendiri. Hal ini sesuai dengan pendapat Hartina (dalam Rosita, Leonad, 2013:7-8), yang memaparkan kelebihan model pembelajaran Think Pair Share yaitu siswa akan terlatih menerapkan konsep karena bertukar pendapat dengan temannya untuk memperoeh kesepakatan dalam memecahkan masalah. Selain itu siswa lebih aktif dalam pembelajaran baik secara individu, berpasangan maupun berkelompok. Penggunaan model Think Pair Share memberikan dampak positif dalam pembelajaran yang dapat dilihat dari proses pembelajaran yang tidak lagi berpusat pada guru melainkan lebih melibatkan siswa, siswa lebih aktif memecahkan permasalahan baik secara individu, berpasangan maupun dalam berkelompok. Model pembelajaran Think Pair Share juga melatih siswa untuk berpikir kritis yaitu menanggapi jawaban yang disampaikan oleh siswa lain maupun kelompok lain untuk mendapatkkan pemecahan masalah yang tepat. Melalui proses pembelajaran yang mengaktifkan dan memberikan 
semangat pada siswa, maka pemahaman konsep materi pelajaran menjadi lebih baik sehingga siswa dapat mencapai hasil belajar yang optimal. Hal ini sesuai dengan pendapat Slavin dalam (Thobroni, 2015) bahwa Think pair Share merupakan sebuah model yang sederhana, tetapi sangat berguna. Langkah-langkah model pembelajaran Think Pair Share diawali dengan guru menyajikan permasalahan kemudian siswa diberi waktu untuk memecahkan masalah secara individu, kemudian bertukar pikiran atau pendapat dengan pasangan, dan kemudian berbagi dalam sebuah kelompok sangat efektif. Menerapkan pembelajaran model Think Pair Share memungkinkan siswa untuk terlibat lebih aktif, memungkinkan siswa untuk menggali pengetahuan dari rekan sekitarnya, memungkinkan siswa untuk berperan lebih penuh dalam belajar, sehingga memungkinkan siswa untuk meningkatkan motivasi belajar dan hasil belajarnya.

Hasil penelitian ini melengkapi dan memperkuat penelitian terdahulu antara lain yang telah dilakukan oleh Sigit Rizkiawan (2013) terkait penggunaan model pembelajaran Think Pair Share untuk meningkatkan motivasi belajar dan hasil belajar Matematika pada siswa kelas IV SD Negeri 01 Ampel Kecamatan Ampel Kabupaten Boyolali, menunjukkan bahwa pada kondisi awal, dari total keseluruhan siswa sebanyak 46 siswa, ditemukan yaitu 24 siswa yang lulus KKM atau 52,17\% kemudian setelah diberikan tindakan perbaikan pada siklus I siswa yang lulus KKM menjadi 36 siswa atau meningkat menjadi $78,26 \%$, pada siklus II 43 siswa lulus KKM dengan prosentase 93,48\%. Motivasi belajar siswa juga meningkat dari siklus I ke siklus II, yaitu pada siklus I motivasi belajar Matematika dengan penerapan model kooperatif tipe Think Pair Share sebesar 72,80\% menjadi $87,66 \%$ pada siklus II. Penelitian serupa juga telah dilakukan oleh Normalasarie, Muhammad Rizki Zukkarnain (2017) dengan menggunakan pembelajaran kooperatif tipe Think Pair Share (TPS) menggunakan alat peraga untuk meningkatkan motivasi dan hasil belajar Matematika pada siswa kelas V SDN Pakauman 1 Banjarmasin menunjukkan telah berhasil meningkatkan hasil belajar dan motivasi siswa. Pada kondisi awal hasil belajar dan motivasi siswa berada di 50\% masih di bawah ketuntasan minimal. Pada siklus pertama diperoleh data dengan kriteria baik, namun ada beberapa siswa yang masih belum memahami konsep. Hasil belajar siswa secara klasikal tuntas sebanyak 60\% sehingga tindakan ini belum mencapai keberhasilan. Setelah perbaikan pembelajaran dilakukan siklus kedua mencapai $80 \%$ dengan rata-rata nilai keseluruhan sebesar 86,31\%. Selain itu penelitian yang telah dilakukan oleh Dian Febriani (2016) terkait penggunaan model pembelajaran Think Pair Share untuk meningkatkan hasil belajar Matematika pada siswa kelas IV SDN Kutowinangun o1 Kota Salatiga, hasilnya menunjukkan peningkatan dari kondisi awal 63,84\% meningkat pada siklus I menjadi $68,71 \%$ dan telah meningkat lagi mencapai $88,43 \%$ pada siklus II. Penelitian seupa juga dilakukan oleh Supardi (2013) dalam meningkatkan hasil belajar matematika melalui pembelajaran Kooperatif Think Pair Share pada siswa kelas IV semester 1 SD Negeri 3 Tambakrejo tahun Pelajaran 2012/2013 telah berhasil. Diketahui hasil penelitian yang dilakukan melalui dua siklus menunjukkan adanya peningkatan pada siklus ke II. Dari hasil analisis didapatkan bahwa prestasi belajar siswa mengalami peningkatan dari siklus I ke siklus II yaitu, siklus I (60,25\%), siklus II (89,00\%). Penelitian juga telah dilakukan oleh Sri Novianti (2013) yaitu peningkatan hasil belajar Matematika melalui model pembelajaran Think Pair Share pada kelas V SDN Karangwage 02 Trangkil Pati Semester 1 tahun pelajaran 2013/2014 berhasil meningkatkan hasil belajar siswa. pada kondisi awal hanya 35\% dari 20 siswa yang memenuhi hasil belajar sesuai KKM 75. Setelah dilakukan tindakan penelitian yang berlangsung dalam dua siklus diketahui hasil penelitian siklus I siswa memperoleh nilai $>75$ mencapai $45 \%$. Pada siklus II telah mengalami peningkatan yaitu siswayang memperoleh nilai >75 mencapai 90\%. Sehingga penelitian yang dilakukan telah berhasil.

\section{E. SIMPULAN DAN SARAN}

Berdasarkan hasil analisis data maka dengan demikian dapat disimpulkan bahwa pembelajaran Think Pair Share dapat meningkatkan motivasi belajar yang ditandai pula dengan meningkatkatnya hasil belajar Matematika pada siswa kelas IV SDN Sidorejo Lor 01 Salatiga Semester 2 Tahun 2017/2018. Hal ini dibuktikan dengan hasil penelitian sebagai berikut:

1. Peningkatan motivasi belajar siswa. Pada siklus I motivasi belajar siswa dalam mengikuti pembelajaran dengan pembelajaran Think Pair Share (TPS) berada pada kategori sedang dengan nilai rata-rata 79,4. Setelah dilakukan perbaikan-perbaikan dengan memberikan peran yang berbeda-beda dalam kelompok, pada siklus II, terjadi peningkatan motivasi belajar siswa dalam mengikuti pembelajaran dengan menggunakan model pembelajaran Think Pair Share (TPS) berada pada kategori tinggi dengan nilai rata-rata 84,4 .

2. Sebelum tindakan, siswa yang tuntas belajar adalah 20 (57\%) dari 35 siswa. Setelah diberikan tindakan pada siklus I, terjadi pertambahan siswa yang tuntas menjadi 22 siswa (63\%). Setelah diberikan tindakan pada siklus II, terjadi lagi peningkatan ketuntasan belajar siswa menjadi 29 (83\%).

Adapun saran bagi sekolah. penggunaan model pembelajaran Think Pair Share dapat dijadikan referensi untuk meningkatan kualitas proses, motivasi dan hasil belajar siswa. Bagi guru hendaknya dapat menerapkan model pembelajaran yang lebih bervariasi 
dalam pembelajaran Matematika salah satunya dengan model pembelajaran Think Pair Share karena dengan model pembelajaran ini dapat menciptakan suasana pembelajaran yang lebih menyenangkan, siswa aktif, komunikasi antar siswa lancar dan lebih semangat belajar. Bagi siswa dalam mengikuti model pembelajaran Think Pair Share harus bersungguhsungguh dan aktif baik dalam kegiatan diskusi maupun tanya jawab, selain itu pada saat dilakukan pembahasan jawaban secara bersama-sama siswa harus lebih memperhatikan agar pemahaman terhadap materi pelajaran dapat tersampaikan dengan baik. Bagi peneliti lain hendaknya penelitian ini dapat dijadikan acuan bagi penelitian selanjutnya sebagai upaya meningkatkan mutu dan kualitas pendidikan.

\section{UCAPAN TERIMA KASIH}

Penulis mengucapkan terimakasih kepada dosen pembimbing tugas akhir, guru dan murid kelas 4 SDN Sidorejo Lor 01 Salatiga yang telah membantu dalam menyelesaikan penelitian ini.

\section{DAFTAR RUJUKAN}

[1] Anam, K. (2015). Pembelajaran Berbasis Inkuiri Metode dan Aplikasi. Yogyakarta: Penerbit Pustaka Belajar.

[2] Huda, M. (2014). Cooperative Learning Metode, Teknik, Struktur dan Model Penerapan. Yogyakarta: Pustaka Pelajar.

[3] N.W.Anggareni, N.P.Ristiati, \& Widiyanti, N. (2013). Implementasi Strategi Pembelajaran Inkuiri Terhadap Kemampuan Berfikir Kritis dan Pemahaman Konsep IPA Siswa SMP. e-Journal Program Pascasarjana Universitas Pendidikan Ganesha , 3.

[4] Silabus Matematika SD versi 2016 hal 7

[5] Peraturan Pemerintah No. 32 tahun 2013 tentang Standar Nasional Pendidikan.

[6] Permendikbud Tahun 2016 Nomor 024 Lampiran 14 halaman 7

[7] Permendikbud No. 64 tahun 2013.

[8] Samatowa, U. (2011). Pembelajaran IPA di Sekolah Dasar. Jakarta: Indeks.

[9] Sugiyono. (2013). Metode Penelitian Kuantitatif, Kualitatif dan $R \& D$. Bandung: Alfabeta.

[10] Suprihatiningrum, J. (2013). Strategi Pembelajaran. Jogjakarta: Ar-Ruzz Media.

[11] (2014). Strategi Pembelajaran. Jogjakarta: Ar-Russ Media.

[12] Suprijono, A. (2011). Cooperative Learning Teori \& Aplikasi PAIKEM. Yogyakarta: Pustaka Pelajar.

[13] Tampubolon, S. (2014). Penelitian Tindakan Kelas Sebagai Pengembangan Profesi Pendidik dan Keilmuan. Jakarta: Erlangga.

[14] Thobroni, M. (2015). Belajar \& Pembelajaran Teori dan Praktik. Yogyakarta: Ar-Ruzz Media.
[15] Undang-Undang tentang Sistem Pendidikan Nasional No. 20 Tahun 2003 Pasal 37 Ayat (1).

[16] Wena, M. (2013). Strategi Pembelajaran Inovatif Kontemporer Suatu Tinjauan Konseptual Operasional. Jakarta: Bumi Aksara.

[17] Wisudawati, A. W., \& Sulistyowati, E. (2014). Metodologi Pembelajaran IPA. Jakarta: Bumi Aksara.

[18] Yustinus. (2017). Startegi Pemecahan Masalah Matematika. Salatiga: Widya Sari Press 